\title{
Impact of Human Resource Development on Public Service Through Employee Performance Of Center Mamuju
}

\author{
Nimrah Rahmayanti Yusuf $A^{1}$, Widyawati $^{2}$, Nurlaela ${ }^{3}$ \\ ${ }^{1,2}$ Public Administration, FISIP Universitas Sembilanbelas November Kolaka \\ ${ }^{3}$ BKPP Kabupaten Mamuju Tengah \\ Email: nimrahr.yusuf@gmail.com
}

\begin{abstract}
Public organizations as a place for providing services to the community must be supported by quality human resources. This is inseparable from the human resource development system, in creating superior human resources and having good performance so that the services provided can increase public satisfaction. The purpose of this study was to determine the impact of human resource development on public service through employee performance of center Mamuju. This research is a quantitative type of research, which is conducted at the Civil Service and Civil Service Agency, Population and Civil Registry Office, and five District Offices in Central Mamuju Regency. The sample in this study amounted to 102 people. Data collection was carried out through distributing questionnaires, observations, interviews, and supporting documents related to the research topic. The results showed that the development of human resources through employee performance influenced the quality of public services in Central Mamuju Regency with an F calculated value of 15.668. greater than the F table, which is 3.09. For the probability value, the value is 0,000 , smaller than 0.05 .
\end{abstract}

Keywords: Human Resource, Service, Performance, Development

\section{INTRODUCTION}

The industrial revolution 4.0 marked by the process of digitizing and using electronic devices to achieve efficiency values (Lestari et al., 2019), has an impact not only on the industrial sector but also on the process of providing public services, (Gruber, 2019; Lestari et al., 2019; Rennung et al., 2016; Roblek \& Krapes, 2016). As seen from the innovations made by several public and private organizations in improving the quality of customer-oriented service, (Classen \& Friedli, 2019; Eprilianto et al., 2019; Padovano et al., 2018).

The success of private organizations in making service innovations cannot be fulfilled by public organizations. Human resource (HR) capacity is one of the reasons for the failure to implement service innovation in public organizations (Atthahara, 2018; Sudarmi et al., 2019; Thamrin et al., 2017; Wardani, 2019), where employees still have an understanding and minimal skills regarding the use of technology, (Atthahara, 2018). This then reinforces the view (Yabanci, 2020) that HR is an important asset for organizations in carrying out activities, in other words, the goal of the organization will be achieved if it is supported by quality human resources.

The importance of human resources in the organization must be supported by the implementation of planned and sustainable human resource development (Andaria et al., 2020). It is intended that HR can work optimally in achieving goals that are in line with the vision and mission of the organization, (Murniyanti, 2014). The implementation of HR development can be 
directed at learning opportunities related to the quality and skills of employees (Tarigan \& Nasution, 2014; Werner \& DeSimone, 2012; Yabanci, 2020). As an initial step in HR development, it can be done through career development and employee talent assessment (Yabanci, 2020).

As a new autonomous region, Central Mamuju District should develop human resources. Because from the author's initial observations, the new autonomous regions have low human resource capacity, human resources work not according to their talents and skills. When someone's working is not by their abilities, it will have an impact on work results that are not optimal, and according to the viewpoint (Nyberg et al., 2013) the success of an organization is measured by employee performance.

Also, one of the goals of the formation of new autonomous regions is to improve the performance of public services to realize the quality and quantity of services (Syukur, 2015), but this is still difficult to achieve. Government employees in the Mamuju Regency in the middle of providing services still use methods that have long been abandoned by government employees in general. When other government employees provide services using technology, government employees of the Central Mamuju district still use manual services.

According to the phenomena above, this study aims to analyze in-depth the effect of human resource development on public services in Central Mamuju Regency through employee performance. It is hoped that the results study can be used as input and consideration for the Central Mamuju Regency government in developing human resources so that the objectives of regional autonomy can be achieved

\section{METHOD}

By the background previously described, this study discusses the effect of human resource development on public services in Central Mamuju District through employee performance, using quantitative methods. The research data obtained from questionnaires distributed to 102 samples, which were further strengthened by the results of observations, interviews, and documents related to the research topic. After the research data was collected, the authors analyzed the data using the multiple linear regression method, this study consist of 3 variables, namely human resource development as an independent variable, public service as the dependent variable, and employee performance as an intervening variable.

\section{RESULT AND DISCUSSION}

\section{Result}

\section{Descriptive Human Resource Development}

The human resource development variable in this study was measured through 4 questions, which presented indicators of the HR development variable, which consisted of 1) Education, and 2) Training. The results of the descriptive analysis of the HR development variables are presented in the following table: 
Table 1.

Descriptive Statistics of HR Development Variables

\begin{tabular}{lccccc}
\hline & N & Minimum & Maximum & Mean & Std. Deviation \\
\hline Education & 102 & 6 & 10 & 9.28 & .860 \\
Training & 102 & 7 & 10 & 8.96 & .770 \\
Valid N (listwise) & 102 & & & & \\
\hline
\end{tabular}

Source: Results of Data Processed Using SPSS 16.0

The table above shows that in human resource development (HR) based on the mean value of the two indicators, namely education, and training, education makes a greater contribution to human resource development.

\section{Descriptive Employee Performance}

Measurement of employee performance variables in this study was carried out through 5 questions that presented indicators of employee performance variables, which consisted of 1) service orientation, 2) commitment, 3) initiative, 4) cooperation and 5) leadership. The results of the descriptive analysis of the service quality variables are presented in the following table:

Table 2.

Descriptive Statistics Of Employee Performance

\begin{tabular}{lccccc}
\hline & N & Minimum & Maximum & Mean & Std. Deviation \\
\hline Service Orientation & 102 & 3 & 5 & 4.57 & .517 \\
Commitment & 102 & 3 & 5 & 4.65 & .500 \\
Initiative & 102 & 4 & 5 & 4.77 & .420 \\
Teamwork & 102 & 4 & 5 & 4.80 & .399 \\
Leadership & 102 & 3 & 5 & 4.55 & .607 \\
Valid N (listwise) & 102 & & & & \\
\hline
\end{tabular}

Source: Results of Data Processed Using SPSS 16.0

From table 2 above, according to the mean value of the employee performance variable indicators, the cooperation indicator provides a large contribution compared to other indicators. Also, for the minimum value of the five indicators of employee performance variables, the indicators of service orientation, commitment and leadership have a value of 3 , while the indicators of initiative and cooperation have a value of 4 . For the maximum value of the five indicators, they get the same value, namely 5 .

\section{Descriptive of Public Service Quality}

The variable of public service quality in this study, the measurement was carried out through 5 questions, which presented indicators of public service variables, which consisted of 1) Reliability; 2) Tangibles; 3) Responsiveness; 4) Assurance, and: 5) Empathy. The results of the descriptive analysis of the service quality variables presented in the following table: 
132 Jurnal Administrare: Jurnal Pemikiran Ilmiah dan Pendidikan Administrasi Perkantoran Volume 8 Issue 1, January-June 2021. Pages 129-142

Table 3.

DescriptiveVariable Public Service Quality

\begin{tabular}{lccccc}
\hline & N & Minimum & Maximum & Mean & Std. Deviation \\
\hline Reliability & 102 & 4 & 5 & 4.68 & .470 \\
Tangibles & 102 & 4 & 5 & 4.47 & .502 \\
Responsiviness & 102 & 4 & 5 & 4.58 & .496 \\
Assurance & 102 & 3 & 5 & 4.64 & .503 \\
Empaty & 102 & 3 & 5 & 4.51 & .522 \\
Valid N (listwise) & 102 & & & & \\
\hline
\end{tabular}

Source: Results of Data Processed Using SPSS 16.0

By results of the descriptive analysis of the public service quality variables that have been presented in table 3 above, it can be seen that the reliability indicator makes a big contribution to the quality of public services, which is followed by assurance, which has a mean difference of only 0.04 .

Regression Analysis The Effect of Human Resource Development on Quality of Public Services.

The impact of human resource development on the quality of public services can be seen from the results of the analysis using a simple linear regression method. The results of the analysis pay attention to the calculated $\mathrm{F}$ value and the significance probability value obtained from data management using SPSS 16.0, which is presented in the table, as involved below:

Table 4.

Regression Analysis The Effect of Human Resource Development on Quality of Public Services

\begin{tabular}{|c|c|c|c|c|c|}
\hline Model & Sum of Squares & df & Mean Square & $\mathbf{F}$ & Sig. \\
\hline Regression & 9.965 & 1 & 9.965 & 4.094 & $.046^{\mathrm{a}}$ \\
\hline Residual & 243.378 & 100 & 2.434 & & \\
\hline Total & 253.343 & 101 & & & \\
\hline
\end{tabular}

a. Predictors: (Constant), HRD

b. Dependent Variable: Public Service

Source: Results of Data Processed Using SPSS 16.0

As previously described, the number of respondents or samples in this study was 102 people, so that the F table value of this study was 3.94. Based on table 4 above, the calculated $F$ value is 4.094. This means that the $\mathrm{F}$ count is greater than the $\mathrm{F}$ table, which is 3.94. The significance probability value obtained is 0.046 , smaller than 0.05 . This means that human resource development has a significant effect on the quality of public services because the calculated $\mathrm{F}$ value obtained from the results of data analysis is greater than the $\mathrm{F}$ table value. 


\section{Regression Analysis The Effect of Human Resource Development on Employee Performance}

To determine the effect of human resource development on employee performance, an analysis was carried out using a simple linear regression method. The results of linear regression analysis on this variable still pay attention to the calculated $F$ value and the significance probability value obtained from data management using SPSS 16.0, which is presented in the table, as seen below:

\section{Table 5.}

Regression Analysis The Effect of Human Resource Development on Employee Performance

\begin{tabular}{lrrrrr}
\hline Model & Sum of Squares & \multicolumn{1}{l}{ df } & Mean Square & \multicolumn{1}{c}{ F } & \multicolumn{1}{c}{ Sig. } \\
\hline $1 \quad$ Regression & 9.825 & 1 & 9.825 & 8.108 & $.005^{\mathbf{a}}$ \\
& 121.166 & 100 & 1.212 & & \\
$\quad$ Residual & 130.990 & 101 & & & \\
$\quad$ Total & & & & & \\
\hline
\end{tabular}

a. Predictors: (Constant), HRD

b. Dependent Variable: Employee Performance

Source: Results of Data Processed Using SPSS 16.0

From the results of the simple linear regression analysis shown in Table 5 above, it is known that the calculated $\mathrm{F}$ value is 8.108 . This means that the $\mathrm{F}$ count is greater than the $\mathrm{F}$ table, which is 3.94 . For the significance probability value, the result is 0.005 , smaller than 0.05 . This means that HR development has a significant effect on employee performance.

\section{Analysis of Employee Performance Regression on Quality of Public Services}

Employee performance on Public Service Quality is known from the results of the analysis using the simple linear regression method, taking into account the calculated $F$ value and the significance probability value. The analysis results are presented in the table, as involved below:

Table 6.

Analysis of Employee Performance Regression on Quality of Public Services

\begin{tabular}{|c|c|c|c|c|c|c|}
\hline \multicolumn{2}{|c|}{ Model } & Sum of Squares & df & Mean Square & $\mathbf{F}$ & Sig. \\
\hline \multirow[t]{3}{*}{1} & Regression & 59.740 & 1 & 59.740 & 30.857 & $.000^{\mathrm{a}}$ \\
\hline & Residual & 193.603 & 100 & 1.936 & & \\
\hline & Total & 253.343 & 101 & & & \\
\hline
\end{tabular}

a. Predictors: (Constant), Employee

Performance

b. Dependent Variable: Public Service Quality

Source: Results of Data Processed Using SPSS 16.0

Based on table 6 above, the calculated $\mathrm{F}$ value is 30.857 . This means that the $\mathrm{F}$ count is greater than the $\mathrm{F}$ table, which is 3.94 . The significance probability value is 0.000 , less than 
134 | Jurnal Administrare: Jurnal Pemikiran Ilmiah dan Pendidikan Administrasi Perkantoran Volume 8 Issue 1, January-June 2021. Pages 129-142

0.05. This means that employee performance has a significant effect on the quality of public services.

\section{Regression Analysis of the Impact of Human Resources Development on Public Service Quality through Employee Performance}

The impact of human resource development on the quality of public services through employee performance is known from the results of the analysis using multiple linear regression methods. The results of the analysis pay attention to the calculated $F$ value, the significance probability value, and the constant value obtained from data management using SPSS 16.0, which is presented in the Anova table and the Coefficients table below:

Table 7.

Regression Analysis of the Impact of Human Resources Development on Public Service Quality through Employee Performance

\begin{tabular}{|c|c|c|c|c|c|c|}
\hline \multicolumn{7}{|c|}{ ANOVA } \\
\hline & del & Sum of Squares & df & Mean Square & $\mathbf{F}$ & Sig. \\
\hline \multirow[t]{3}{*}{1} & Regression & 60.909 & 2 & 30.454 & 15.668 & $.000^{\mathrm{a}}$ \\
\hline & Residual & 192.434 & 99 & 1.944 & & \\
\hline & Total & 253.343 & 101 & & & \\
\hline
\end{tabular}

a. Predictors: (Constant), Employee Performance, HR Development

b. Dependent Variable: Public Service Quality

Source: Results of Data Processed Using SPSS 16.0

Table 8.

Coefficients of the Impact of Human Resources Development on Public Service Quality through Employee Performance

\begin{tabular}{|c|c|c|c|c|c|c|}
\hline \multicolumn{7}{|c|}{ Coefficients } \\
\hline & \multirow{2}{*}{ Model } & \multicolumn{2}{|c|}{$\begin{array}{l}\text { Unstandardized } \\
\text { Coefficients }\end{array}$} & \multirow{2}{*}{$\begin{array}{c}\begin{array}{c}\text { Standardized } \\
\text { Coefficients }\end{array} \\
\text { Beta } \\
\end{array}$} & \multirow[t]{2}{*}{$\mathbf{t}$} & \multirow{2}{*}{ Sig. } \\
\hline & & B & Std. Error & & & \\
\hline \multirow[t]{3}{*}{1} & (Constant) & 5.792 & 3.315 & & 1.747 & .084 \\
\hline & HR Development & .107 & .137 & .071 & .776 & .440 \\
\hline & $\begin{array}{l}\text { Employee } \\
\text { Performance }\end{array}$ & .648 & .127 & .466 & 5.119 & .000 \\
\hline & Dependent Variable:I & Service Q & uality & & & \\
\hline
\end{tabular}

Source: Results of Data Processed Using SPSS 16.0

Human resource development influences the quality of public services through employee performance if the calculated $\mathrm{F}$ value obtained in the Anova table from the results of data analysis is greater than the $\mathrm{F}$ table value, and based on table 7 above, the calculated $\mathrm{F}$ value 
obtained is 15.668 , greater from $\mathrm{F}$ table that is 3.09 . For the significance probability value in the Annova table, the value is 0,000 , smaller than 0.05 . This means that human resource development has a significant effect on the quality of public services through employee performance.

Furthermore, the constant value shown in table 8 is 5.792, indicating that public services with human resource development and employee performance will increase by 5.792. Also, if human resource development is equal to zero, then the value of public services is 0.107 . When human resource development has increased by 1 unit, then public services will increase by 0.107. Furthermore, if the employee's performance is equal to zero, then the value of public service is 0.648 . When employee performance has increased by 1 unit, then public services will increase by 0.648 .

\section{Discussion}

\section{The Impact of Human Resource Development on Public Services}

Human resource development is an activity carried out to improve the abilities, skills, and knowledge of employees (Werner \& DeSimone, 2012; Yabanci, 2020). Human resource development carried out in Mamuju Tengah District includes providing education and training. Human resource development through education and training directed at shaping employee figures as state servants who provide services to the community in a professional, fair and equitable manner.

The results of data analysis showed that the mean value of education in human resource development was 9.28, and the mean value for training was 8.96. The mean of the two indicators is greater than the standard deviation. It shows that the human resource development variable is in a fine category. It was also known that education provides a greater contribution to the development of human resources.

Training has differences, so there are often differences in the impact on human resource development. Education is more aimed at increasing general knowledge and understanding as a whole (Practical Theory), while training leads to an effort to increase the knowledge and skills of employees to do certain jobs (practical theory).

Most of the employees who work in public service agencies in the Mamuju Tengah District have higher educational backgrounds. From the research data, it shows that $83.34 \%$ of employees have backgrounds, namely graduates of Diplomas, Bachelors and Masters. Only about $16.66 \%$ of employees have a high school education background/equivalent. The high level of employee education is supported by the employee recruitment system in Central Mamuju District. One of the requirements that must be met for prospective employees is the level of education that has at least a Diploma and Bachelor's degree. Thus, in general, a Bachelor's education background takes precedence.

Also, employee awareness of the benefits of education for careers and job responsibilities is a supporting factor for the high education of employees in Central Mamuju District. Even though employees do not get tuition assistance from the local government, and have to pay their expenses, it does not discourage employees from continuing their education. Government efforts to support employee education, namely by permitting employees to continue their education, both within the region and outside the region. 
Employees' awareness of continuing education, according to the viewpoint (Tomlinson, 2012), is a potential for digging themselves up to better understand the work they are currently doing. Besides that, according to the opinion (Sato et al., 2021), employee education can increase knowledge about the profession or job that is being done so that employees can apply the theories obtained in carrying out work.

Furthermore, about providing training for employees, the Central Mamuju Regency government carried out the provision of basic training for new employees. Also, the government provided other employees with other training, which was following their respective fields, such as training. and financial management education, training and education for the procurement of goods and services, training and education for mental revolution. However, the implementation of the training is not carried out routinely and is only intended for certain people who hold important positions in the organization.

The provision of training should be provided to all employees, especially employees who work in the field of public services because their duties are directly related to the community. According to the view (Yabanci, 2020), providing training can realize agencies in achieving goals, through the skills, skills, and attitudes of employees. So this shows that providing training for employees is very necessary to achieve organizational goals in Central Mamuju District to provide optimal service. From the findings (Chiang et al., 2015) it is also known that providing training will provide valuable experience to employees, which in turn can affect employee work results, so that employee performance improves, which then has a positive impact on organizational performance.

Human resource development in Central Mamuju District, although there are still shortcomings in terms of providing training, does not affect human resource development, so it can be said that human resource development in Central Mamuju District has been going well. This is also in line with the results of research conducted by (Pakpahan et al., 2014) where the provision of training does not have a significant effect on employee performance such as education, but its role in developing employee performance at the Regional Civil Service Agency of Malang City is quite good.

The implementation of good human resource development can realize the provision of quality services to the community. The results of the research analysis showed that the significance value of human resource development was 0.046 , less than 0.05 . This means the development of human resources in public service agencies in Central Mamuju District has a significant effect on the quality of public services. When employees have good education and skills, providing services will result in good service quality.

From the data analysis of research in public service agencies in Central Mamuju Regency, namely the Office of the Education and Training Personnel Agency, the Population and Civil Registration Service, the Tobadak District Office, the Topoyo District Office, the Panigale District Office, the Karossa District Office, and the Budong-Budong District, shows that the five indicators used to observe service quality in Central Mamuju Regency, namely reliability, tangibles, responsiveness, assurance, and empathy, as previously described, have a mean value greater than the standard deviation, which means the quality of public services in Central Mamuju Regency. are in a good category.

The educational background of the employees of the public service agencies of Central Mamuju Regency, who are in the good category, is one of the supporting factors for the quality of service in the Central Mamuju Regency. Because with education, employees have an 
understanding and knowledge of the procedures for providing good services to the community, which they get from formal education and the implementation of education and training held by the government.

Employees in the public service agency of Central Mamuju Regency have also understood that the most important thing in providing services to the community is community satisfaction. So that in providing services to the community, employees, and leaders make standard operating procedures which they use as guidelines in providing services. Employees also understand that in providing services to the community, the appearance of employees can affect the level of community satisfaction. So that in providing services, employees always try to give their best appearance by dressing neatly, giving a smile to the community, and being friendly. This action is carried out by employees to provide a good perception to the community about the services provided. This is in line with the findings of research conducted by (Nur \& Seran, 2019) that the most important thing in providing services to the community is how public service can build customer perceptions.

On the other hand, employees also understand that in the process of providing services, the community needs a clear time for completion, so that employees always provide information to the public about the time they need to complete what the community wants. When the work cannot be completed on the same day, the employee will encourage the community to come the next day at the set time.

Time certainty in providing services is needed because most of the causes of service in public organizations are categorized as not quality due to the inability of service providers to provide certainty of time. As the results of research conducted by (Anindita \& Dwimawanti, 2016) that of the five indicators of public services, two indicators of service still get a poor rating. One of the indicators is assurance, where the indicator is related to the ability of employees to provide certainty about the time for completing the service.

Furthermore, about the effect of training on public services in Central Mamuju District, it is known that they have applied the experience of the employees they received from implementing the training in providing services. One example of implementing the results of employee training is the procurement of goods. Employees at public service agencies in Central Mamuju Regency have procured goods that are very much needed by the community during the public service process, such as adding waiting seats. Where before the existence of training on procurement of goods, employees only prepare a few waiting chairs, but after training, employees increasingly understand that procurement of goods is not only related to the real evidence of the goods, but procurement of goods must be following needs, and most importantly for public service agencies, procurement of goods can affect the level of satisfaction and public trust in the organization and make it easier for employees to carry out their duties.

\section{The Effect of Employee Performance on Public Services}

Performance is basically what employees do or don't do. Performance can also be said to be a comparison between work results and work standards that have been determined. Employee performance is very important for an organization so that every organization will make efforts to improve employee performance based on the results of employee performance appraisals.

In the public service agency of Central Mamuju Regency, an assessment of employee performance is carried out by taking into account five indicators of performance variables, namely: service orientation, commitment, initiative, cooperation, and leadership already in the 
good category. From the results of the research analysis described in the previous chapter, it is known that all variables have a mean value greater than the standard deviation. The performance of employees in Kabupaten Mamuju Tengah has a very good level of cooperation.

The results showed that the value of employee cooperation in work was 4.80. Also, the level of employee initiative in work shows a value of 4.77. Apart from cooperation and initiative, employees also have a good commitment. The results showed a value of 4.65. For service orientation and leadership, the results of the presentation are greater than 4.50.

Also, from the data of simple linear regression analysis, it is known that the significance probability value obtained is 0.000 , less than 0.05 . This means that the performance of employees in Central Mamuju District has a significant effect on the quality of public services. Judging from the service orientation indicators, employees in providing services to the community are friendly, the behavior of employees while providing servants is very polite. Employees do not allow the community to wait a long time to get services, so this makes the community feel satisfied with the services provided by employees in the public service agency of Central Mamuju Regency.

The commitment indicator, employees have the willingness to understand the desires of the community, this certainly facilitates communication between employees and the community during the service delivery process. So that the results of the service received are following the expectations of the community and provide a sense of satisfaction. Meanwhile, in the work initiative indicator, it can be seen that providing services to the community is getting easier. Employees have used online-based applications. The willingness of employees to innovate on work provides good performance results. Whereas in the indicators of cooperation, employees make cooperative relationships as the right solution when facing problems in providing services to the community, so that the services provided produce maximum efficiency and usefulness.

The most important thing in providing public services is the impact of a leader. In the public service agency of Central Mamuju Regency, the leader has carried out his role as well as possible. Leaders are active in motivating employees to work optimally. This certainly encourages employees to carry out their responsibilities.

The results of this study which found a positive influence on employee performance on public services have the same results of research conducted by (Mananeke et al., 2019) and (Bismawati, 2016) even though the performance indicators used are different. The results of the study (Bismawati, 2016) show that Individual Competence, Organizational Support, and Management Support which are indicators of employee performance simultaneously (simultaneously) have a significant effect on the quality of public services in the Regional Disaster Management Agency of Mamuju Utara Regency. Besides that, the results of the research (Mananeke et al., 2019) show that the performance of employees measured based on indicators of quality, quantity, implementation of duties and responsibilities has a positive effect on service quality at the Puskesmas, Lembeh Utara District, Bitung City.

\section{The Influence of Human Resource Development on Public Services through Employee Performance}

Providing human resource development in the form of training and education can help employees to realize good service quality, which is of course supported by the performance of the employees themselves. The results of the analysis of research data using multiple linear 
regression, it is known that the calculated $\mathrm{F}$ value of 15.668. greater than the $\mathrm{F}$ table, which is 3.09. For the probability value, the value is 0,000 , smaller than 0.05 . This means that human resource development has a significant effect on the quality of public services through employee performance.

The knowledge, skills, and abilities of employees in public service agencies in Central Mamuju Regency obtained during education and training when they are expected to do their jobs will result in a good performance, which in turn will result in quality public services. Conversely, when employees are unable or trying to apply knowledge and experience while carrying out education and training, of course, it will not improve their performance, so that the services provided will not be able to satisfy the community.

Based on education and employee training experience, the performance of employees at the Central Mamuju Regency public service agency is getting better, so this is what causes the quality of service in the Middle Mamuju Regency to be in a good category. Judging from the indicators of reliability in public services, employees in providing services to the community have been able to provide satisfying and reliable services wherein providing services, employees have understood very well what can satisfy the community. So that employees at work behave as well as possible and with high accuracy.

The tangibles indicator, the quality of service to the community can be fulfilled, because employees have provided a good appearance, creating a safe, clean and cool office condition. And for the indicator of responsiveness, employees always welcome the community with a friendly smile, employees do not allow the community to wait without clarity, therefore every employee sees the community coming, the employee immediately goes over and asks the purpose of the community's arrival.

For assurance indicators, employees can provide services following what they promised to the community. And from the indicators of empathy, employees can communicate well with the community, so this is what makes it easier for employees to understand the desires of the community, and the service delivery process can run smoothly

\section{CONCLUSION}

Human resource development (HR) through employee performance has a significant effect on public services in Central Mamuju District. Education has a great influence on HR development. A good level of education makes initiatives and employee cooperation relations better so that the provision of services to the community can be carried out appropriately and correctly. For the implementation of public services to be of higher quality in Mamuju Tengah District, the government needs to provide intensive training, so that employees not only have initiative and good cooperative relationships but also have commitment and leadership in carrying out their duties. Also, the Central Mamuju Regency government needs to increase the awareness of employees about their duties as state servants in providing services, so that employees can increase their responsiveness and empathy. 
140 Jurnal Administrare: Jurnal Pemikiran Ilmiah dan Pendidikan Administrasi Perkantoran Volume 8 Issue 1, January-June 2021. Pages 129-142

\section{REFERENCES}

Andaria, K. S., Xaverius E Lobja, Hermon Maurits Karwur, \& Recky H. E. Sendouw. (2020). Capability Development Efforts of Human Resources in Furniture Industry at Leilem Village Minahasa Regency. Jurnal Administrare: Jurnal Pemikiran Ilmiah Dan Pendidikan Administrasi Perkantoran, 7(2), 269-276.

Anindita, F., \& Dwimawanti, I. H. (2016). Analisis Kualitas Pelayanan di Unit Pelaksanaan Teknis Pemeliharaan Kesehatan Masyarakat Surakarta. Journal of Public Policy and Management, 5(3), 165-176.

Atthahara, H. (2018). novasi Pelayanan Publik Berbasis E-Government: Studi Kasus Aplikasi Ogan Lopian Dinas Komunikasi dan Informatika di Kabupaten Purwakarta. Jurnal Politikom Indonesiana, 3(1), 66-77.

Bismawati. (2016). Pengaruh Kinerja Pegawai terhadap Kualitas Pelayanan Publik di Badan Penanggulangan Bencana Daerah Kabupaten Mamuju Utara. E-Jurnal Katalogis, 4(3), 112.

Chiang, Y.-H., Hsu, C.-C., \& Shih, H.-A. (2015). Erratum to: Experienced high performance work system, extroversion personality, and creativity performance. Asia Pacific Journal of Management, 32(825), 531-549.

Classen, M., \& Friedli, T. (2019). Value-Based Marketing and Sales of Industrial Services: A systematic literature review in the age of digital technologies. Procedia CIRP, 83, 1-7.

Eprilianto, D. F., Sari, Y. E. K., \& Saputra, B. (2019). Mewujudkan Integrasi Data Melalui Implementasi Inovasi Pelayanan Kesehatan Berbasis Teknologi Digital. Journal of Public Sector Innovations, 4(1), 30-37.

Gruber, H. (2019). Proposals for a digital industrial policy for Europe. Telecommunications Policy, 43(2), 116-127.

Lestari, T. D., Fajar, R. S., \& Desiana Reni D. (2019). Desiana Reni. In I. T. Sihidi, A. Roziqin, \& I. D. Maulana (Eds.), Tantangan di Era Industri 4.0 dalam Implementasi Kebijakan Pelayanan Publik di Perindustrian dan Perdagangan Kota Mojokerto (pp. 1456-1469). Asosiasi Ilmu Pemerintahan Perguruan Tinggi Muhammadiyah.

Mananeke, T. D. W., Rares, J. J., \& Tampongangoy, D. (2019). Pengaruh Kinerja Pegawai terhadap Kualitas Pelayanan di Puskesman Kecamatan Lembeh Utara Kota Bitung. EJournal Universitas Sam Ratulangi, 1(1), 1-5.

Murniyanti, S. (2014). Pengaruh Kompetensi Sumber Daya Manusia terhadap Efektivitas Kerja Karyawan pada PT. Kawasan Wisata Pantai Cermin Theme Park dan Resort Hotel. Jurnal Ilmu Ekonomi Dan Studi Pembangunan, 14(1), 66-72.

Nur, M., \& Seran, M. S. B. (2019). Service Quality of Border Region Higher Education Libraries. Jurnal Administrare: Jurnal Pemikiran Ilmiah Dan Pendidikan Administrasi Perkantoran, 6(2), 145-152.

Nyberg, A. J., Pieper, J. R., \& Trover, C. O. (2013). Pay-for-Performance's Effect on Future 
Employee Performance: Integrating Psychological and Economic Principles Toward a Contingency Perspective. Journal of Management, 20(10), 1-31.

Padovano, A., Longo, F., Nicoletti, L., \& Mirabelli, G. (2018). A Digital Twin based Service Oriented Application for a 4.0 Knowledge Navigation in the Smart Factory. IFACPapersOnLine, 51(11), 631-636.

Pakpahan, E. S., Siswidiyanto, \& Sukanto. (2014). Pengaruh Pendidikan dan Pelatihan terhadap Kinerja Pegawai (Studi pada Badan Kepegawaian Daerah Kota Malang). Jurnal Administrasi Publik, 2(1), 116-121.

Rennung, F., Luminosu, C. T., \& Draghici, A. (2016). Service Provision in the Framework of Industry 4.0. Procedia - Social and Behavioral Sciences, 221(7), 372-377.

Roblek, M., \& Krapes. (2016). A Complex View of Industry 4.0. Sage Publication.

Sato, S., Kang, T.-A., Daigo, E., Matsuoka, H., \& Harada, M. (2021). Graduate employability and higher education's contributions to human resource development in sport business before and after COVID- 19. Journal of Hospitality, Leisure, Sport \& Tourism Education, $28,1-11$.

Sudarmi, S., Sunusi, S., \& Syam, A. (2019). Development of human resources In the perspective of the career development of teachers at the State Vocational School in Makassar City. Jurnal Ad'ministrare, 6(1), 45-50.

Syukur, A. T. (2015). Dampak Pembentukan Kabupaten Mamasa Provinsi Sulawesi Barat Terhadap Peningkatan Kesejahteraan Rakyat dan Pelayanan Publik. AKPP (Jurnal Analisis Kebijakan Dan Pelayanan Publik), 1(1), 55-75.

Tarigan, C. G., \& Nasution, M. A. (2014). Pengaruh Pengembangan Sumber Daya Manusia Terhadap Kinerja Karyawan Pada PT. PLN Cabang Binjai. Jurnal Ilmu Administrasi Publik, 2(2), 146-153.

Thamrin, M. H., Dewi, E., Ridho, H., \& Salam, R. S. (2017). Model Legislative Candidate Recruitment In Province (Case Study in Golkar Party and the Indonesian Democratic Party of Struggle on North Sumatera Province and Central Java, 2014). 2nd International Conference on Social and Political Development (ICOSOP 2017).

Tomlinson, M. (2012). Graduate employability: A review of conceptual and empirical themes. Higher Education Policy, 25(4), 407-431.

Wardani, A. K. (2019). Urgensi Inovasi Pelayanan Bidang Administrasi Publik di Era Disrupsi. Jurnal Ilmiah Ilmu Administrasi Negara, 6(2), 30-35.

Werner, J., \& DeSimone, R. L. (2012). Human resource development. United States.

Yabanci, O. (2020). From Human Resource Management to Intelligent Human Resource Management: a Conceptual perspective. Human-Intelligent Systems Integration, 11-20. 
142 | Jurnal Administrare: Jurnal Pemikiran Ilmiah dan Pendidikan Administrasi Perkantoran Volume 8 Issue 1, January-June 2021. Pages 129-142

This page is intentionally left blank 